Bangl. J. Vet. Med. (2005). 3 (1): 75-77

\title{
EFFECTS OF ARSENIC ALONE AND IN COMBINATION WITH SELENIUM, IRON AND ZINC ON CLINICAL SIGNS, BODY WEIGHT AND HAEMATOBIOCHEMICAL PARAMETERS IN LONG EVANS RATS
}

\author{
M. N. Islam, M. A. Awal, M. M. Rahman, M. S. Islam and M. Mostofa
}

Department of Pharmacology, Faculty of Veterinary Science, Bangladesh Agricultural University, Mymensingh-2202, Bangladesh

\begin{abstract}
The effects of selenium, iron and zinc supplementation along with arsenic on clinical signs, body weight and haematobiochemical parameters were studied in 25 mature male long Evans rats (Ratus norvegicus) of one month old during the period from August to October 2003. These 25 rats were randomly divided into five equal groups (A, B, C, D and E) of which rats of group A received normal feed and water and rats of group B were given arsenic trioxide $\left(\mathrm{As}_{2} \mathrm{O}_{3}\right) @ 400$ mg / liter plus sodium selenite (NaSe) @ $1 \mathrm{mg} /$ liter; rats of group $\mathrm{C}$ were given $\mathrm{As}_{2} \mathrm{O}_{3} @ 400 \mathrm{mg} /$ liter plus ferrous sulfate $\left(\mathrm{FeSO}_{4}\right) @ 150 \mathrm{mg} /$ liter; rats of group D were given $\mathrm{As}_{2} \mathrm{O}_{3} @ 400 \mathrm{mg} /$ liter plus zinc sulfate $\left(\mathrm{ZnSO}_{4}\right) @ 50 \mathrm{mg} /$ liter and rats of group E were given only As $\mathrm{O}_{3} @ 400 \mathrm{mg} /$ liter drinking water daily for 42 days. All the rats of groups B, C and D showed very mild toxic signs, i.e., excitement, restlessness, anorexia, ruffled hair coat, salivation and mild skin lesion on tail region. Rats of group $\mathrm{E}$ (only $\mathrm{As}_{2} \mathrm{O}_{3}$ ) showed various toxic signs like excitement, restlessness, anorexia, ruffled hair coat, salivation, muscle tremor, ataxia, incoordination and posterior paralysis. All the toxic signs observed in group E were more severe and skin lesions were found in all parts of the body especially on tail region. Rats of group E showed highly significant $(\mathrm{p}<0.01$ ) decrease in body weight, total erythrocyte count, Hb content and packed cell volume (PCV). On the other hand highly significant $(\mathrm{p}<0.01)$ increase of ESR values were recorded in group E. Biochemical examination revealed that the activities of serum glutamate pyruvate transaminase (SGPT) and serum glutamate oxaloacetate transaminase (SGOT) were significantly $(\mathrm{p}<0.01$ ) elevated in all the treated groups than that of control. But in the rats which were treated only with arsenic trioxide, the elevation of SGPT and SGOT were much higher than other treated groups. It may be concluded that the combined administration of $\mathrm{NaSe}, \mathrm{FeSO}_{4}$ or $\mathrm{ZnSO}_{4}$ along with $\mathrm{As}_{2} \mathrm{O}_{3}$ were found to be less toxic than administration of $\mathrm{As}_{2} \mathrm{O}_{3}$ alone because selenium, iron, and zinc have protective effects against some toxic effects of arsenic.
\end{abstract}

Key words: Arsenic, selenium, iron, zinc, haematological parameters, rats

\section{INTRODUCTION}

Arsenic poisoning is one of the most important recent problems in Bangladesh. It is important for public health as well as for livestock. The ground water arsenic poisoning in Bangladesh was first confirmed in 1993 in Chapai Nawabgonj District (Smith et al., 2001). Almost 57 million people in Bangladesh (around 40\% populations) are at risk for cancer and other diseases because of arsenic contaminated tube-well water (Mohammad, 2002). Ground water in 59 out of 64 districts of Bangladesh is contaminated by deadly arsenic (Shafiuddin and Karim, 2002). Arsenic is ubiquitous in nature, i.e., present in all natural resources like soils, rocks, water, organisms, plants, atmosphere, etc. Most of the arsenic related environmental problems are the result of mobilization under natural conditions. However, man has an important additional impact through different activities such as combustion of fossil fuel, the use of arsenical pesticides, herbicides, crop desiccants and the use of arsenic as an additive to livestock feed, particularly for poultry. The use of arsenical compound for wood preservation is still common. The impact on the environment of the use of arsenical compounds will remain for some years. Many scientists from different countries are working on the arsenic problem in Bangladesh but no one has come up with an explanation based on convincing evidence that pinpoints the source of arsenic that is poisoning the people of Bangladesh. So, considering all possible factors, this pioneering work has been undertaken to determine the effects of feeding arsenic trioxide alone and in combination with selenium, iron and zinc in rats by observing toxic signs, body weight and haematobiochemical parameters.

\section{MATERIALS AND METHODS}

The experiment was carried out in the Experimental Pharmacology and Toxicology Laboratory, Department of Pharmacology, Faculty of Veterinary Science, Bangladesh Agricultural University, Mymensingh during the period from August to October 2003. A total of 25 one-month-old male Long Evans rats were used in this experiment. All the rats were kept under close observation in order to acclimatize to the new environment for a period of one week. All the rats maintained on good housing conditions and were provided with normal feed and water. After acclimatization they were randomly divided into 5 equal groups, each consisting of five rats and were marked as group A, B, C, D and E. 
Among 5 groups, one group of rats (group A) was kept as control fed with normal feed and water while the remaining groups were received arsenic trioxide @ $400 \mathrm{mg} /$ liter drinking water daily for 42 days. In addition, groups B, C and D were treated with sodium selenite@1 mg / liter, ferrous sulfate@150 mg / liter and zinc sulfate@ 50 mg / liter drinking water respectively daily for 42 days and observed carefully for appearance of toxic signs.

Body weight of the control and treated rats were taken before commencement of treatment and then weekly during 42 days of feeding. Blood samples were collected from the tail vein of all the groups in screw capped vial with and without anticoagulant at day 0 and day 42 for haematological and biochemical studies respectively. The haematological parameters were determined as per method cited by Lamberg and Rothstein (1977). The biochemical parameters were performed by UV method using IFCC (International Federation of Clinical Chemistry) used Humalyzer 2002 (Human type, Germany).

Data were analyzed statistically by Student's ' $t$ ' test (Bailey, 1981).

\section{RESULTS AND DISCUSSION}

Rats of group A (control group) were quite normal during the whole experimental period. Rats of groups B (arsenic trioxide@400 mg / L plus sodium selenite@1 mg / L), C (arsenic trioxide @ 400 mg / L plus ferrous sulfate @ 150mg / L) and D (arsenic trioxide @ 400 mg / L plus zinc sulfate @ 50mg / L) showed very mild toxic signs, i.e., excitement, restlessness, anorexia, salivation and very mild skin lesion found on tail region. Rats of group E (only arsenic trioxide @ $400 \mathrm{mg} / \mathrm{L}$ ) showed various toxic sings like excitement, restlessness, anorexia, salivation, muscle tremor, ruffled hair coat, ataxia, posterior paralysis, incoordination, reduced feed consumption. Many other authors reported clinical signs similar to the present findings (Harding et al., 1968; Confer et al., 1980; Riviere et al., 1981; Balatskii, 1989 and Blackley et al., 1990). The mean body weight of rats of group B, C and D were decreased gradually but not significant statistically (Table 1).

Table 1. Effect of arsenic trioxide alone and in combination with selenium, iron and zinc supplementation on mean body weight in rats (Mean \pm SE)

\begin{tabular}{|llllll|}
\hline Days & $\begin{array}{l}\text { Group A } \\
(\text { Control }) \\
(\mathrm{n}=5)\end{array}$ & $\begin{array}{l}\text { Group B } \\
\left(\mathrm{As}_{2} \mathrm{O}_{3} @ 400 \mathrm{mg} / \mathrm{L}\right. \\
+\mathrm{NaSe} @ 1 \mathrm{mg} / \mathrm{L}) \\
(\mathrm{n}=5)\end{array}$ & $\begin{array}{l}\text { Group C } \\
\left(\mathrm{As}_{2} \mathrm{O}_{3} @ 400 \mathrm{mg} / \mathrm{L}\right. \\
\left.+\mathrm{FeSO}_{4} @ 150 \mathrm{mg} / \mathrm{L}\right) \\
(\mathrm{n}=5)\end{array}$ & $\begin{array}{l}\text { Group D } \\
\left(\mathrm{As}_{2} \mathrm{O}_{3} @ 400 \mathrm{mg} / \mathrm{L}\right. \\
\left.+\mathrm{ZnSO}_{4} @ 50 \mathrm{mg} / \mathrm{L}\right) \\
(\mathrm{n}=5)\end{array}$ & $\begin{array}{l}\text { Group E } \\
\left(\mathrm{Only} \mathrm{As}_{2} \mathrm{O}_{3}\right. \\
(\mathrm{n}=5)\end{array}$ \\
\hline 0 & $178.94 \pm 7.50$ & $184.66 \pm 5.37$ & $179.56 \pm 9.76$ & $176.22 \pm 11.33$ & $183 \pm 4.85$ \\
7 & $184 \pm 7.45$ & $180.12 \pm 5.44$ & $177.2 \pm 9.92$ & $174.8 \pm 11.10$ & $179.38 \pm 4.76$ \\
14 & $188.8 \pm 7.22$ & $178.28 \pm 5.15$ & $175.68 \pm 8.88$ & $172.08 \pm 10.22$ & $173.04 \pm 4.9$ \\
21 & $192.4 \pm 7.4$ & $175.94 \pm 5.17$ & $172.26 \pm 8.18$ & $170.2 \pm 10.12$ & $167.78 \pm 5.21$ \\
28 & $196.50 \pm 8.81$ & $173.12 \pm 4.35$ & $170.08 \pm 8.24$ & $169.18 \pm 9.84$ & $163.2 \pm 5.05 *$ \\
35 & $200.8 \pm 8.86$ & $170.32 \pm 4.59$ & $168.10 \pm 7.47$ & $167.76 \pm 9.91$ & $158.82 \pm 5.20^{* *}$ \\
42 & $202 \pm 9.12$ & $168.24 \pm 8.68$ & $165.5 \pm 6.81^{*}$ & $165.7 \pm 9.62$ & $152.6 \pm 5.10^{* *}$ \\
\hline
\end{tabular}

$\mathrm{n}=$ Number of rats weighed, $* *$ Significant at $\mathrm{p}<0.01$, *Significant at $\mathrm{p}<0.05$.

In group $\mathrm{E}$ decrease in body weight was highly significant $(\mathrm{p}<0.01)$ at 35 and 42 days of treatment. A similar result on body weight was observed by many other workers (Byron et al., 1967; Suren, 1977; Confer et al., 1980). Total erythrocyte count (TEC) and haemoglobin content $(\mathrm{Hb})$ were slightly reduced and packed cell volume (PCV) significantly $(\mathrm{p}<0.05)$ reduced in groups $\mathrm{B}, \mathrm{C}$ and $\mathrm{D}$ but highly significant $(\mathrm{p}<0.01)$ reduction of TEC, Hb content and PCV were observed in group E (Table 2). In contrast to TEC, Hb content and PCV, ESR value was slightly increased in groups B, C and D but significantly $(\mathrm{p}<0.01)$ increased in group E. Variable haematological values have been reported by Klassen (1991). It may be assumed that toxic effects induced by arsenic trioxide on bone marrow may be responsible for erythrocytopenia and leukocytosis observed in this study. 
Effects of arsenic in rats

Table 2. Effect of arsenic trioxide alone and in combination with selenium, iron and zinc supplementation on certain haematobiochemical parameters in rats

\begin{tabular}{|c|c|c|c|c|c|c|c|c|c|c|}
\hline \multirow[t]{2}{*}{ Parameters } & \multicolumn{2}{|c|}{$\begin{array}{l}\text { Group A } \\
\text { (Control) } \\
(\mathrm{n}=5)\end{array}$} & \multicolumn{2}{|c|}{$\begin{array}{l}\text { Group B } \\
\left(\mathrm{As}_{2} \mathrm{O}_{3} @ 400 \mathrm{mg} / \mathrm{L}\right. \\
+\mathrm{NaSe} @ 1 \mathrm{mg} / \mathrm{L}) \\
(\mathrm{n}=5)\end{array}$} & \multicolumn{2}{|c|}{$\begin{array}{l}\text { Group C } \\
\left(\mathrm{As}_{2} \mathrm{O}_{3} @ 400 \mathrm{mg} / \mathrm{L}\right. \\
\left.+\mathrm{FeSO}_{4} @ 150 \mathrm{mg} / \mathrm{L}\right) \\
(\mathrm{n}=5)\end{array}$} & \multicolumn{2}{|c|}{$\begin{array}{l}\text { Group D } \\
\left(\mathrm{As}_{2} \mathrm{O}_{3} @ 400 \mathrm{mg} / \mathrm{L}\right. \\
\left.+\mathrm{ZnSO}_{4} @ 50 \mathrm{mg} / \mathrm{L}\right) \\
(\mathrm{n}=5)\end{array}$} & \multicolumn{2}{|c|}{$\begin{array}{l}\text { Group E } \\
\left(\text { Only } \mathrm{As}_{2} \mathrm{O}_{3}\right. \\
@ 400 \mathrm{mg} / \mathrm{L}) \\
(\mathrm{n}=5)\end{array}$} \\
\hline & $\begin{array}{l}\text { Pre- } \\
\text { dosing }\end{array}$ & $\begin{array}{l}\text { Post- } \\
\text { dosing }\end{array}$ & $\begin{array}{l}\text { Pre- } \\
\text { dosing }\end{array}$ & $\begin{array}{l}\text { Post- } \\
\text { dosing }\end{array}$ & $\begin{array}{l}\text { Pre- } \\
\text { dosing }\end{array}$ & $\begin{array}{l}\text { Post- } \\
\text { dosing }\end{array}$ & $\begin{array}{l}\text { Pre- } \\
\text { dosing }\end{array}$ & $\begin{array}{l}\text { Post- } \\
\text { dosing }\end{array}$ & $\begin{array}{l}\text { Pre- } \\
\text { dosing }\end{array}$ & $\begin{array}{l}\text { Post- } \\
\text { dosing }\end{array}$ \\
\hline $\begin{array}{l}\text { TEC } \\
\left(10^{6} / \mathrm{cmm}\right)\end{array}$ & $\begin{array}{l}7.936 \\
\pm 0.91\end{array}$ & $\begin{array}{l}7.959 \\
\pm 0.13\end{array}$ & $\begin{array}{l}7.935 \\
\pm 0.07\end{array}$ & $\begin{array}{l}7.554 \\
\pm 0.22\end{array}$ & $\begin{array}{l}7.938 \\
\pm 0.16\end{array}$ & $\begin{array}{l}7.755 \\
\pm 0.05\end{array}$ & $\begin{array}{l}7.936 \\
\pm 0.14\end{array}$ & $\begin{array}{l}7.724 \\
\pm 0.18\end{array}$ & $\begin{array}{l}7.937 \\
\pm 0.18\end{array}$ & $\begin{array}{r}* * 4.668 \\
\pm 0.14\end{array}$ \\
\hline $\begin{array}{l}\mathrm{Hb} \\
(\mathrm{g} \%)\end{array}$ & $\begin{array}{l}8.00 \\
\pm 0.22\end{array}$ & $\begin{array}{l}8.25 \\
\pm 0.17\end{array}$ & $\begin{array}{l}8.06 \\
\pm 0.06\end{array}$ & $\begin{array}{l}7.70 \\
\pm 0.98\end{array}$ & $\begin{array}{l}8.12 \\
\pm 0.11\end{array}$ & $\begin{array}{l}7.80 \\
\pm 0.12\end{array}$ & $\begin{array}{l}8.20 \\
\pm 0.12\end{array}$ & $\begin{array}{l}7.68 \\
\pm 0.25\end{array}$ & $\begin{array}{l}8.00 \\
\pm 0.22\end{array}$ & $\begin{array}{c}* * 6.10 \\
\quad \pm 0.18\end{array}$ \\
\hline $\begin{array}{l}\text { PCV } \\
(\%)\end{array}$ & $\begin{array}{l}35.00 \\
\pm 1.00\end{array}$ & $\begin{array}{l}35.20 \\
\pm 1.12\end{array}$ & $\begin{array}{l}35.25 \\
\pm 0.94\end{array}$ & $\begin{array}{r}* 30.85 \\
\pm 0.95\end{array}$ & $\begin{array}{l}35.45 \\
\pm 0.46\end{array}$ & $\begin{array}{r}* 32.60 \\
\pm 0.75\end{array}$ & $\begin{array}{l}35.00 \\
\pm 0.94\end{array}$ & $\begin{array}{c}* 30.85 \\
\pm 0.95\end{array}$ & $\begin{array}{l}35.01 \\
\pm 0.50\end{array}$ & $\begin{array}{r}* * 26.80 \\
\pm 0.37\end{array}$ \\
\hline $\begin{array}{l}\text { ESR (mm } \\
\text { in } 1^{\text {st }} \text { hour) }\end{array}$ & $\begin{array}{l}0.5 \\
\pm 0.16\end{array}$ & $\begin{array}{l}0.55 \\
\pm 0.09\end{array}$ & $\begin{array}{l}0.5 \\
\pm 0.16\end{array}$ & $\begin{array}{l}* 0.85 \\
\pm 0.03\end{array}$ & $\begin{array}{l}0.5 \\
\pm 0.16\end{array}$ & $\begin{array}{l}0.72 \\
\pm 0.22\end{array}$ & $\begin{array}{l}0.5 \\
\pm 0.16\end{array}$ & $\begin{array}{l}0.73 \\
\pm 0.09\end{array}$ & $\begin{array}{l}0.5 \\
\pm 0.16\end{array}$ & $\begin{array}{l}* * 4.2 \\
\quad \pm 0.37\end{array}$ \\
\hline $\begin{array}{l}\text { SGPT } \\
(\mathrm{U} / \mathrm{L})\end{array}$ & $\begin{array}{l}160 \\
\pm 0.14\end{array}$ & $\begin{array}{l}163 \\
\pm 0.16\end{array}$ & $\begin{array}{l}161 \\
\pm 0.95\end{array}$ & $\begin{array}{c}* * 180.50 \\
\pm 0.25\end{array}$ & $\begin{array}{l}162 \\
\pm 0.97\end{array}$ & $\begin{array}{c}* * 190.62 \\
\pm 0.14\end{array}$ & $\begin{array}{l}162 \\
\pm 0.96\end{array}$ & $\begin{array}{c}* * 181.78 \\
\pm 0.22\end{array}$ & $\begin{array}{l}163.35 \\
\pm 0.84\end{array}$ & $\begin{array}{l}* * 220 \\
\pm 0.12\end{array}$ \\
\hline $\begin{array}{l}\text { SGOT } \\
(\mathrm{U} / \mathrm{L})\end{array}$ & $\begin{array}{l}165 \\
\pm 0.12\end{array}$ & $\begin{array}{l}165 \\
\pm 0.25\end{array}$ & $\begin{array}{l}163 \\
\pm 0.94\end{array}$ & $\begin{array}{l}* * 183 \\
\quad \pm 0.16\end{array}$ & $\begin{array}{l}164 \\
\pm 0.99\end{array}$ & $\begin{array}{l}* * 195 \\
\quad \pm 0.14\end{array}$ & $\begin{array}{l}165 \\
\pm 0.94\end{array}$ & $\begin{array}{l}* * 178 \\
\quad \pm 0.22\end{array}$ & $\begin{array}{l}166 \\
\pm 0.97\end{array}$ & $\begin{array}{rl}* * & 230 \\
\pm 0.12\end{array}$ \\
\hline
\end{tabular}

Pre-dosing at day 0 of commencement of experiment, Post-dosing at 42 days of treatment, $\mathrm{n}=$ Number of blood samples, $* *$ Significant at $\mathrm{p}<0.01, *$ Significant at $\mathrm{p}<0.05$.

Biochemical examination revealed that the activities of serum glutamate pyruvate transaminase (SGPT) and serum glutamate oxaloacetate transaminase (SGOT) were significantly $(\mathrm{p}<0.01)$ elevated in all the treated groups than that of control. But in the rats which were treated only with arsenic trioxide, the elevation of SGPT and SGOT were much higher than other treated groups. The present findings could not be compared with the findings of other workers due to lack of available literature on biochemical parameters. It may be concluded that arsenic is highly toxic both for man and laboratory animals and some cheap chemicals like selenium, iron and zinc supplementation may be helpful in reducing arsenic toxicity.

\section{REFERENCES}

1. Bailey NTJ (1981). The use of ' $t$ '-test for small samples. In: Statistical Methods in Biology. $2^{\text {nd }}$ edn., Hodder and Stoughton, Great Britain.

2. Balatskii KP (1989). Clinical and pathological features of arsenic poisoning in fowls. Veterinariya Moskova 9: 61-63.

3. Blackley BR, Clark EG and Fairley R (1990). Roxarsone (3- nitro-4 hydroxyphenylarsenilic acid) poisoning in pigs. Canadian Veterinary Journal 31: 385-387.

4. Byron WR, Bierbower GW, Brouwer JB and Hansen WH (1967). Effects of feeding sodium arsenite or arsenal to rats and dogs. Toxicology and Applied Pharmacology 10: 132-147.

5. Confer AW, Ward BC and Hines FA (1980). Arsenilic acid toxicity in rabbits. Laboratory Animal Science 30: $234-236$.

6. Harding JDJ, Lewis G and Done JT (1968). Experimentally induced arsenic poisoning in pigs. Veterinary Research 83: 560-564.

7. Klassen CD (1991). Heavy metals antagonists. In: Goodman \& Gilman's The Pharmacological Basis of Therapecutics by Hardman JG, Limbrid LE, Molinoff PB, Ruddon RW and Gilman AG (eds.), 8 ${ }^{\text {th }}$ edn., Vol. 1 \& 2 Maxwell McMillian International Editions, New York, USA.

8. Lamberg SL and Rothstein R (1977). Laboratory Manual of Hematology and Urinalysis. Avi Publishing Company, Inc., Westport Connecticut, USA.

9. Mohammad SAI (2002). Arsenic the silent killer. The Bangladesh Observer, $9^{\text {th }}$ May, 2002.

10. Riviere JE, Boosinger TR and Everson RJ (1981). Inorganic arsenic toxicosis in cattle: A review of selected cases. Modern Veterinary Practice 62: 209-211.

11. Shafiuddin M and Karim MM (2002). Arsenic contamination of ground water in Bangladesh: alternative options for safe water. The Bangladesh Observer, $11^{\text {th }}$ May 2002.

12. Smith E, Lingas O, and Rahman M (2001). Contamination of drinking water by arsenic in Bangladesh: a public health hazard. The Daily Star, $22^{\text {nd }}$ March 2001.

13. Suren K (1977). Arsenic residues in slaughter pigs after feeding arsenilic acid. Inaugural Dissertation, Fachbereich Tiermedizin, Muchen. 115 pp. 